\title{
Attachment, Working Models of Self and Others, and God Concept in Kindergarten
}

\author{
SIMONE A. DE ROOS \\ SIEBREN MIEDEMA \\ JURJEN IEDEMA
}

\begin{abstract}
An attachment theoretical model of individual differences in God concepts among kindergarteners was tested. Subjects were 72 kindergarteners (mean age 63 months) from two elementary schools. Children's concepts of self, other, and God were measured using structured questionnaires. A questionnaire and an incomplete doll story procedure were used to tap the quality of the teacher-child and mother-child relationship. The model was partly supported. Contrary to our expectations, a punishing concept of God was not related to any of the independent variables. However, in line with the model, harmony and closeness in the teacher-child relationship predicted a loving God concept and this association was explained by children's working models of self. Working models of others predicted a loving God concept. Although the child's representation of the mother-child attachment relationship was significantly connected to the teacher-child relationship, it was not predictive of the concept of God.
\end{abstract}

\section{INTRODUCTION}

The concept of God has often been considered crucial in the development and form of an individual's personal faith and, therefore, has been studied more than any other religious concept during the past few decades. The concept of God also has been widely researched among children and youth (Hyde 1990). However, previous investigators of God concepts in preschool and kindergarten children have, for the most part, concentrated on age differences in God concepts, focusing mainly on the role of cognitive development in God concepts. We know relatively little about the origins of individual differences in God concepts at a given age, especially in young children (Tamminen 1991). By the term "God concept" we allude to the affective or evaluative aspect of the mental representation of God. It considers the positive or negative value a child assigns to God (i.e., a caring, loving God or a distant, stern, punishing, rejecting God image). For the connotation of the concept of God, we exclusively refer to the broad Western Christian tradition here.

We propose that attachment theory may provide a useful conceptual framework for understanding these differences (Kirkpatrick 1999). In the present study we examine an attachment theoretical model (see Figure 1) of individual differences in God concepts in which we suggest that the quality of the caregiver-child relationship is connected with the valence of children's God concept and that this connection is mediated by children's "working models," i.e., concepts of self and significant others.

Bowlby (1973) claimed that a child develops working models of self and of caregivers in the context of first attachments. Working models are mental representations of self and significant others that are derived from a variety of experienced and observed interactions of the child

Simone A. de Roos is a Researcher in Educational Sciences, Free University of Amsterdam, Department of Philosophy and History of Education, Van der Boechorststraat 1,1081 BT Amsterdam, The Netherlands.Email: SA.de.Roos@psy.vu.nl Siebren Miedema is an Associate Professor in Philosophy of Education and Hendrik Pierson Professor for Christian Education, Free University of Amsterdam, Department of Philosophy and History of Education, Van der Boechorststraat 1, 1081 BT Amsterdam, The Netherlands.

Jurjen Iedema is a Researcher and Methodologist, Social and Cultural Planning Office, P.O. Box 16164, 2500 BD Den Haag, The Netherlands.

Journal for the Scientific Study of Religion 40:4 (2001) 607-618 


\section{FIGURE 1 \\ A CORRESPONDENCE MODEL OF INTERRELATIONS AMONG ATTACHMENT AND CONCEPTS OF SELF, OTHERS, AND GOD}

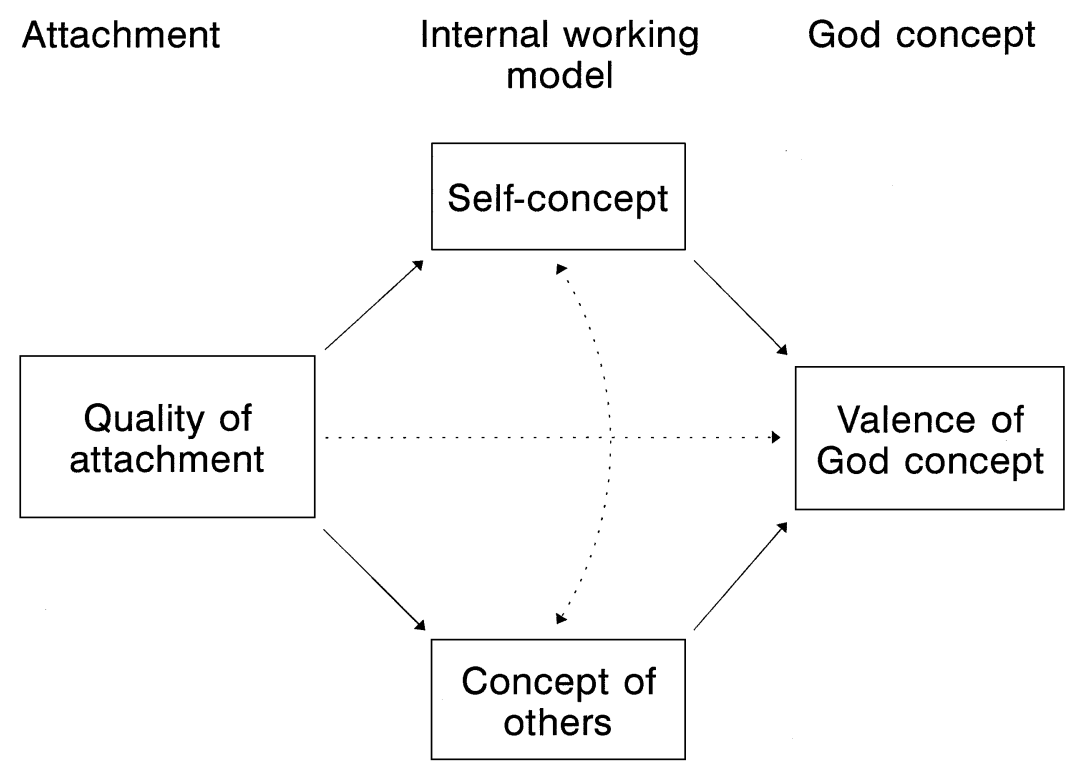

with his or her caregivers. These mental representations come to govern children's perceptions and behavior in new settings and relationships (Bretherton 1985), for example, in their relationship with God. Internal working models of God are supposed to parallel those developed within close relationships. The (in)security of a child's attachment relationship with parents should predict the child's God concept directly. This means that securely attached children should have more positive, loving and less negative, rejecting God concepts than insecurely attached children because they have formed more positive working models of self and significant others.

In the present study we examine the mother-child attachment relationship as well as the quality of the teacher-child relationship in predicting children's God concepts. Entering kindergarten, the teacher is a potential secondary attachment figure (Goossens and Van IJzendoorn 1990; Howes and Matheson 1992). There is a growing body of evidence suggesting that the teacher-child relationship is important for children's cognitive and socioemotional competence in school (Howes, Hamilton, and Matheson 1994; Pianta 1997).

Support for the relationship of attachment with aspects of faith among adults was shown by Kirkpatrick and Shaver (1992), who demonstrated relations between attachment style to partners and religious belief and behavior. Adults who are securely attached to their lovers reported greater religious commitment and more positive images of God than insecurely attached respondents. Anxious, ambivalent respondents were the most likely to report glossolalia experiences, and avoidant respondents were the most likely to describe themselves as agnostic. Some findings of Tamminen (1991) support the hypothesized link between attachment and God concept, although he did not study the security of the parent-child attachment relationship, but rather children's and young people's (grades five and nine) perceived closeness of the parent-child relationship. A close relationship with parents, indicated, for example, by the amount of companionship with parents, is connected to the concept of God as close, real, caring, and forgiving (Tamminen 1991). Religiously committed students, especially girls, find home safer, more caring, cozier, and more stimulating than do other students (Tamminen 1991). 
To show a mediating role of working models in the prediction of God concept, working models should be related both to attachment relationship as well as to God concept. The relation of attachment with God concept should become weaker when working models are included in the analysis. In the present study, working models of self were operationalized as perceived competence (Harter and Pike 1984) and behaviorally presented self-esteem (Haltiwanger 1989). Working models of others were defined as perceived social acceptance (Kobak and Skeery 1988). In a growing number of recent studies, evidence has been found for relations among attachment and working models (Brennan and Bosson 1998), as well as among working models and God concept (Blaine, Trivedi, and Eshleman 1998). However, these studies have mainly been undertaken among young people and adults.

Concerning the connection between attachment and working models, Sroufe (1983) found that teacher-rated self-esteem of preschoolers was predicted by the security of the mother-child attachment relationship in infancy. The concurrent connection between attachment and working models of self and others in kindergarteners has been examined by Cassidy (1988), Verschueren, Marcoen, and Schoefs (1996), and Verschueren and Marcoen (1999). Results of these studies showed that attachment security to caregivers based on observations of the child's reunion behavior and/or on responses to incomplete doll stories was positively related to perceived cognitive competence, perceived peer acceptance, global self-esteem, positive self-descriptions, and behaviorally presented self-esteem. In adults, several studies demonstrated secure attachment to be related to high self-esteem, positive self-views, self-liking, and perceived positive social relations. Preoccupied individuals described themselves as low in self-esteem and low in feelings of competence in managing activities. Avoidant participants described themselves as socially avoidant (Bartholomew and Horowitz 1991; Brennan and Bosson 1998; Brennan and Morris 1997; Collins and Read 1990; Feeney and Noller 1990; Mikulincer 1995).

With regard to associations between working models and God concepts, Kirkpatrick (1998) found among college students that God images correspond with one's internal working models of self and others. Positive mental models of self were related with loving God images and a less distant God. Positive mental models of others were related to a less distant God and to a perceived personal relationship with God. Studies on images of parents (working models of significant others) and of God have shown similarities between these images (for a review, see Hyde 1990). In a study with four- to eleven-year-olds, Dickie, Eschleman, Merasco, Shepard, Vander Wilt, and Johnson (1997) showed that the father's nurturance was most important for perceiving God as nurturing, while the mother's power was most important for perceiving God as powerful.

Studies on the interrelations among concepts of self, parents, and God in Catholic high school youth (Benson and Spilka 1973; Smith, Weigert, and Thomas 1979; Spilka, Addison, and Rosensohn 1975) and college students (Blaine, Trivedi, and Eshleman 1998; Buri and Mueller 1993; Ellison 1993) confirmed proposed connections in our model. Generally, these concepts were significantly correlated. Closeness to parents and loving and nurturing parent images were related to positive self-perceptions and self-esteem. A loving, nurturing parent image was found to go with a loving, comforting, and nurturing God concept. Perceptions of self as loving or controlling were positively related to similar views of God. High self-esteem was connected to a loving God. Subjects with low self-esteem conceived God as wrathful and rejecting. However, the relation of self-evaluations with God concepts in young children has not yet been examined in research. The earlier-mentioned study of Dickie, Eschleman, Merasco, Shepard, Vander Wilt, and Johnson (1997) is the first to include young children's self-perceptions of behavioral characteristics (i.e., nurturance and power) as predictors of God concepts. For their first sample, children's self-ratings were not related to God concepts. For their second sample, children's self-ratings of power were positively related to perceptions of God's power.

In sum, findings of empirical studies lend support for the validity of our proposed model of individual differences in the valence of God concepts. However, these studies involved 
predominantly adolescents and adults. In addition, we are not aware of any research that investigated attachment, concept of self and others, as well as God concept in one single study. Our purpose for the present study is to examine these interrelations concurrently among kindergarteners and to test the hypothesis that children with a less optimal caregiver-child relationship will develop a more negative and less positive concept of God than children having a more optimal relationship with their caregivers because the former have formed a more negative concept of self and others.

\section{METHOD}

\section{Subjects}

The sample consisted of 72 children, 36 boys and 36 girls, aged between 50 and 83 months (mean $=63$ months). They were randomly selected from six different classes in a public ${ }^{1}(N=32)$ and a Protestant $(N=40)$ school in Nijmegen, a medium-sized Dutch city. The children came from low- to middle-class families. Of the children in the public school, 15 children received no religious education at school or at home, whereas 17 did. Of the children in the Protestant school, 30 children came from nonreligious homes and received religious education at school only. Ten of these 40 children were raised Christian both at home and at school.

\section{Measures and Procedures}

\section{Overview}

All children were interviewed individually by a female examiner in a 30-minute session to assess their God concepts, working models, and attachment representations. The children were taken from their kindergarten classes to a separate room. At the end of the session, the children received a stickerform. The different parts of the interview session were given in the same order for each child. First, in order to get acquainted with the interview procedure and the experimenter, the children were asked to draw a picture of God and to tell something about the drawing. Second, they answered open questions about the nature of God (e.g., what is God, where is God, what is God able to do, etc.), which will not be described here further. After that, they completed the pictorial scale of perceived competence and social acceptance, referring to working models of self and others. Then, the children were presented a 23 -item structured questionnaire concerning characteristics of God. Finally, the child's mother-child attachment representations were measured using a doll family.

Measures of the child-teacher relationship and the child's self-esteem (working model of self) were derived from the Student Teacher Relationship Scale and the Behavioral Rating Scale of Presented Self-Esteem, respectively. Both scales were completed by the kindergarten teachers.

To assess dimensions of child-teacher relationship, perceived competence and acceptance, behaviorally presented self-esteem, and God concept, principal components factor analyses with varimax rotation were conducted over the items of each measure. A minimum eigenvalue of 1.00 and the scree test were used as criteria for extracting factors. Based on these factors, scales were constructed for each measure. Items with absolute factor scores $>0.4$ were included in the scales. For each of the measures, scale scores were computed for each subject by averaging the subject's scores on the constituent items. Internal consistencies of the scales were measured by Cronbach's $\alpha$. 


\section{Adult-Child Relationships}

Representation of Mother-Child Attachment Relationship. The Attachment Story Completion Task was used to tap children's representations of attachment relationships with mother (Verschueren and Marcoen 1999). Each child was asked to use a Lego ${ }^{\circledR}$ Belville doll family to complete three attachment-related story beginnings (child screams that an unfamiliar child is stealing the child's bicycle, child gives a present to mother, and child is yelling that there is a monster in the bedroom).

All stories were audiotaped and coded from verbatim transcripts by a coder blind to all other information about the child. Each story was coded independently, without any knowledge about the child's other stories.

Each of the three stories was rated on a five-point scale for attachment security and was placed into one of four attachment categories. Stories received a score of 4 and 5 and were classified as "secure" if children portrayed positive and open interactions with a responsive attachment figure and completed the stories with little hesitation. "Insecure" stories received a score of 1 or 2 for attachment security. Stories were categorized as insecure-avoidant if the parent-child interactions in the story were minimal or when the child was reluctant to answer the experimenter's probes. Responses were classified as insecure-bizarre/ambivalent when the child described negative, hostile, or disorganized interactions with the parent, which could be alternated with scenes of harmonious interactions (Verschueren and Marcoen 1999:186). A story that was neither clearly secure nor insecure was coded as "in between" and given a score of 3 (for criteria for scoring, see Verschueren and Marcoen 1994). In the present study, we used the security scores of each of the three stories as indices of attachment representations in further analyses.

To assess interrater reliability, the mother-child stories of 50 (of 72) randomly selected participants were coded independently by a second coder. Intercoder reliability was substantial, $r=0.82, p<0.0005, \kappa=0.67, p<0.0005$.

Child-Teacher Relationship. The Student Teacher Relationship Scale (STRS; Pianta 1996) was employed to measure the quality of the child-teacher relationship. It is a teacher-report instrument that uses a five-point Likert-type format to assess a teacher's feelings and beliefs about his or her relationship with a particular student, the student's interactive behavior with the teacher, and the teacher's beliefs about the student's feelings toward the teacher (Pianta 1996). Principal component factor analysis over the first 27 items (item 28 was skipped, due to missings on 20 cases; one teacher did not answer this question for her pupils) resulted in three dimensions. They are called conflict, closeness, and dependency. The conflict scale (10 items; $\alpha=0.92)$ contains items such as: "This child and I always seem to be struggling with each other." "This child easily becomes angry with me." and "When this child is in a bad mood, I know we're in for a long and difficult day." The closeness scale ( 5 items; $\alpha=0.79$ ) includes items such as: "I share an affectionate, warm relationship with this child." "If upset this child will seek comfort from me." and "This child spontaneously shares information about him- or herself." The dependency scale ( 8 items; $\alpha=0.77$ ) consists of items such as: "This child reacts strongly to separation from me." "This child asks for my help when s/he does not really need help." and "This child is overly dependent on me." Scale scores on conflict, closeness, and dependency were used in further analyses.

\section{Working Models of Self and Others}

Perceived Competence and Perceived Acceptance by Mother and Peers. The Pictorial Scale of Perceived Competence and Social Acceptance for Young Children (Harter and Pike 1984) probes the young child's feelings about the self in four different domains: (1) cognitive competence (e.g., good at counting), (2) physical competence (e.g., good at swinging), (3) peer acceptance (e.g., has friends to play with), and (4) maternal acceptance (e.g., mom cooks your favorite foods). 
This 24-item questionnaire is administered individually and uses a pictorial format and two-point scales. A sample (cognitive competence) item is: "This girl/boy (in this picture) is good at puzzles (score 2), but that girl/boy (in the other picture) is not very good at puzzles (score 1). Which child is most like you?" The psychometric properties of the instrument were found to be acceptable (Harter and Pike 1984). Originally, the items are rated on a four-point scale (Is the child in the picture a lot like you (either score 1 or 4 ) or just a little (either score 2 or 3)? In an earlier study (De Meester and Verkerk 1999) among 93 kindergarteners, the use of the four-point scale was found to be very time consuming and boring for the children. In addition, correlating the items based on a two- and four-point scale yielded an excellent agreement, the intercorrelations lay between 0.75 and 0.97 . These correlations were Fisher Z-transformed, averaged, and transformed back to a correlation coefficient resulting in $r=0.90$.

A principal component factor analysis over the 24 items resulted in three dimensions: perceived maternal acceptance (11 items: numbers 4, 5, 6, 8, 12, 16, 17, 19, 20, 22, 24; $\alpha=0.81$ ), perceived peer acceptance ( 4 items: numbers $2,10,14,18 ; \alpha=0.86$ ), and perceived (physical and cognitive) competence ( 9 items: numbers $1,3,7,9,11,13,15,21,23 ; \alpha=0.61$ ). Intercorrelations among these scales were 0.42 of perceived acceptance by mother with perceived acceptance by peers, 0.31 of perceived acceptance by mother with perceived competence, and 0.39 between perceived acceptance by peers and perceived competence. Scale scores on perceived competence were used in further analyses as indices of self-concept and scale scores on perceived acceptance by mother and peers as indices of concepts of others.

Behavioral Manifestations of Self-Esteem. The Behavioral Rating Scale of Presented SelfEsteem (Haltiwanger 1989; Haltiwanger and Harter 1988) was employed to assess the behavioral manifestations of self-esteem in four- to seven-year-old children. This questionnaire has 15 items, rated by the child's teacher on a four-point scale, and having a structure alternative format. A sample item is: "Lacks confidence to approach challenging tasks; shies away from challenge" versus "Approaches challenging tasks with confidence." The teacher first has to choose the description that fits the child best and then must decide whether the child is "very much" (either score 1 or 4) or only "sort of" (either score 2 or 3 ) like the child in the description. Based on a principal components factor analysis, three dimensions were tapped: self-esteem (self-confidence, initiative, setting high goals, 7 items; $\alpha=0.93$ ), involved (sociable and assertive, 5 items; $\alpha=0.89$ ), and positive emotions (showing joy and pride easily, 3 items; $\alpha=0.68$ ). Scale scores were used in further analyses.

\section{God Concept}

A 23-item questionnaire was used to measure children's concept of God. The items are intended to involve both positive and negative valence of God concepts. The items were read by the experimenter. Children rated each item on a three-point (no, sometimes, or yes) scale. Principal component factor analysis over these 23 items resulted in two scales, called loving God (positive valence, God loves me, God is my friend, God makes me happy, 5 items; $\alpha=0.76$ ) and punishing God (a more negative valence, God punishes, God scares me, God is angry, 7 items; $\alpha=0.71)$. Scale scores on loving God and punishing God were used in the analyses as dependent variables.

\section{Analysis}

To test our theoretical model, structural equation modeling was used. Results of the structural equation modeling are shown in path diagrams (Figures 2 and 3). In these diagrams, observed variables are drawn in rectangles, which here serve as the indicators for the unobserved latent variables, depicted in ellipses. Straight lines with one arrow represent an effect of one variable to another ("paths"). Curved lines with two arrows represent a correlation between two exogenous 
FIGURE 2

STANDARDIZED ESTIMATES OF CHILD-CARETAKER ATTACHMENT AND THE CHILD'S GOD CONCEPT

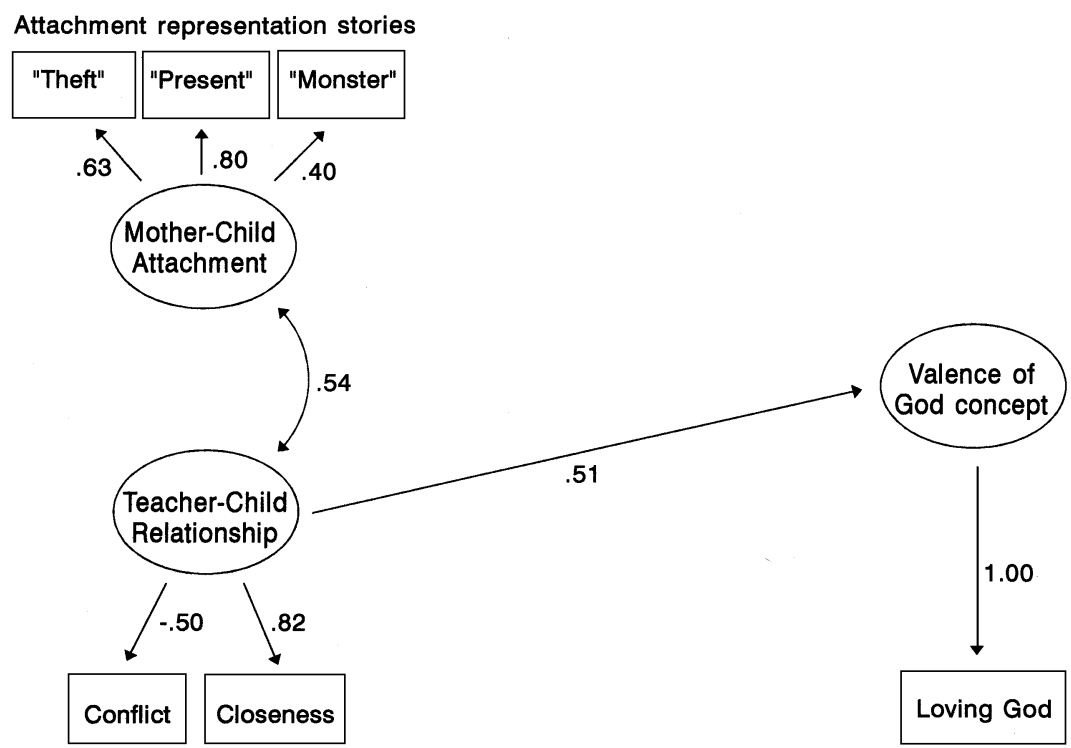

FIGURE 3

STANDARDIZED ESTIMATES OF CHILD-CARETAKER ATTACHMENT AND THE CHILD'S GOD CONCEPT MEDIATED BY SELF-CONCEPT

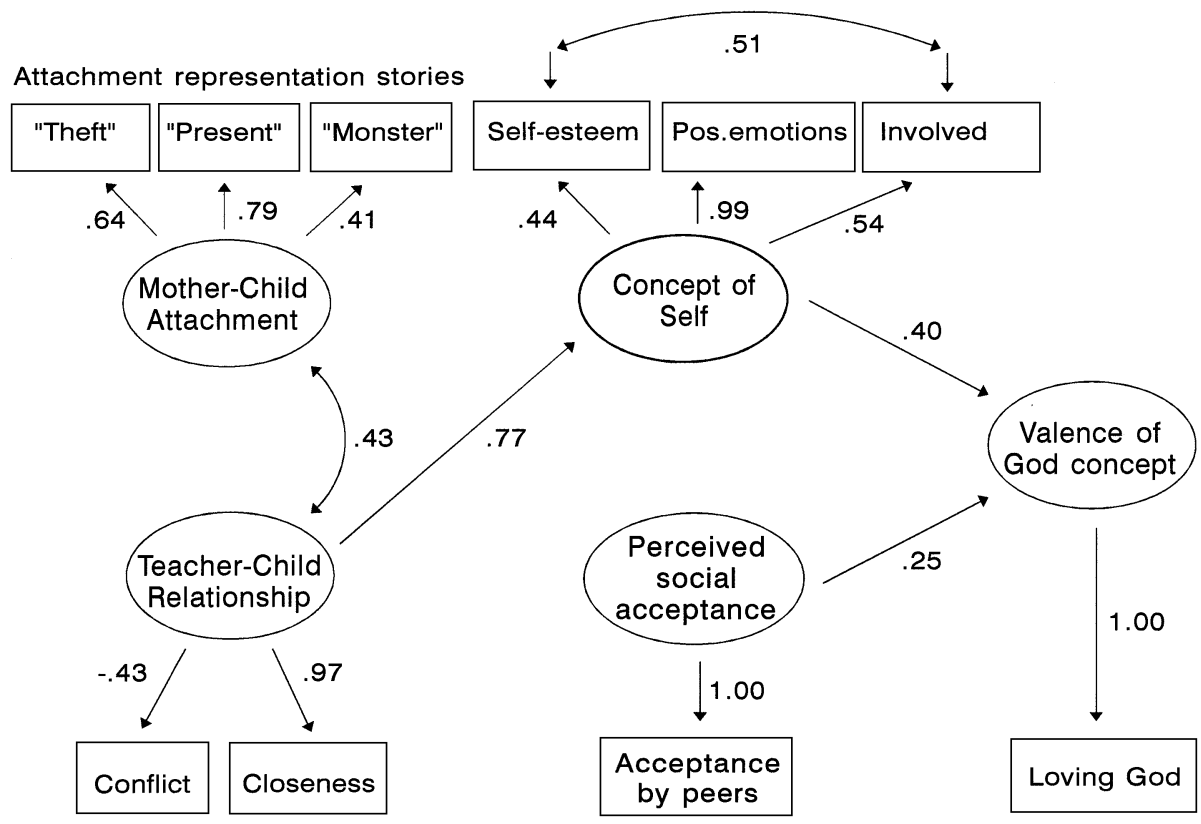


(predictor) variables (in Figures 2 and 3 ) or an error correlation (a correlation between the residuals of two variables) between two endogenous (dependent) variables (in Figure 3).

\section{Results}

First of all, there were no predictors that showed a significant relation with a punishing God concept. Thus, our hypotheses that the quality of caregiver-child relationships predicts a punishing God concept and that concepts of self and others are related to a punishing God concept were not confirmed. There were also some predictors-perceived competence, perceived acceptance by mother, and dependency in the child-teacher relationship — that showed no significant associations with other variables in Lisrel analyses and, therefore, were skipped.

As mentioned in the Introduction, we wanted to test the hypothesis that children with a less optimal relationship with their caregivers will develop a less positive, loving concept of God than children having a more optimal relationship with their caregivers because the former have formed a more negative and less positive concept of self and others. In order to do so, we first have to test whether "mother-child attachment" and "teacher-child relationship" are related to valence of God concept (loving God). Next, we have to test the mediational role of "concept of self" (working model of self) and "perceived social acceptance" (working model of others) - that is, testing whether there is a significant relation from adult-child relationship to working models, which in turn shows a significant relation with a loving God concept. Furthermore, for complete mediation the relation from caregiver-child relationships to loving God concept should disappear when working models are included in the analysis.

Thus, the first step in testing our theoretical model in predicting a loving God concept is to analyze the relation of caregiver-child relationships with a loving God. Figure 2 shows the structural equation model (Lisrel 8; Jöreskog and Sörbom 1993) with one connection among caregiver-child relationship and a loving God concept. The model fits well: $\chi^{2}(7)=5.11, p=$ 0.65; Goodness of Fit Index $(\mathrm{GFI})=0.98$; Adjusted GFI $(\mathrm{AGFI})=0.93$; Root Mean Square Residual $(\mathrm{RMR})=0.05$ (satisfactory values are a nonsignificant $\chi^{2}$, GFI $>0.90$, AGFI $>0.80$, and RMR $<0.05$ ).

As expected, the quality of the child-teacher relationship was related to a loving God concept. Less conflict and more closeness in the child-teacher relationship led to a more loving God concept in kindergarteners. The explained variance of loving God is $\left(0.51^{2}=\right) 26 \%$. The mother-child attachment representation was positively related (0.54) to the teacher-child relationship, but had no effects on the child's God concept.

The second step in testing the model is to include working models of self and others in the analysis. Figure 3 shows the path diagram of the structural equation model. Fit statistics of the model are: $\chi^{2}(30)=36.67, p=0.19 ; \mathrm{GFI}=0.91$; $\mathrm{AGFI}=0.84 ; \mathrm{RMR}=0.075$. These statistics indicate an adequate fit. The explained variance of loving God is $\left(0.40^{2}\right.$ (effect of concept of self) $+0.25^{2}$ (effect of perceived social acceptance) $+(0.77 * 0.40)^{2}$ (indirect effect of teacher-child relationship through working models of self) $=) 32 \%$. The hypothesis concerning the mediating role of the concept of self and others was supported for the concept of self. The explained variance of the concept of self is 60 percent. As can be seen in Figure 3, there is no path between childteacher relationship and God concept when concept of self is included in the analysis. Thus, working models of self are mediators in the connection between child-teacher relationship and loving God. As predicted in the hypothesis, a more optimal (more closeness and less conflict) child-teacher relationship resulted in a more positive self-concept (higher self-esteem, showing more positive emotions, and greater involvement in groups), which led to a more loving God concept. In sum, the child-teacher relationship had positive effects on a loving God concept via the self-concept. Working models of others, i.e., perceived acceptance by peers, led to a more loving God image (0.25), but was not predicted by attachment. 


\section{Discussion}

The goal of the present study was to extend prior research in the area of antecedents of God concepts in early childhood by examining an attachment theoretical model of individual differences in the valence of God concepts among kindergarteners. In the model it is suggested that the quality of caregiver-child relationships is associated with the valence of God concepts and that this association is mediated by children's working models, i.e., concepts of self and significant others.

The results of the present study show a positive connection between the quality of the childteacher relationship and a loving God concept. This connection was mediated by children's working models of self. More specifically, young children with a close, open, and harmonious relationship with their teacher showed positive emotions, high involvement in groups, and had high self-esteem, which led to a loving, caring God concept. Children who have a less close and more discordant relationship with their teacher showed less positive emotions and involvement, and lower self-esteem than children with a close relationship with their teacher, which resulted in a less loving God concept. As far as we know, this is the first study to demonstrate concurrent connections among kindergarteners' relationships with teachers, their behaviorally presented selfesteem, and the valence of their God concept.

One of the most striking findings in this study is that the child-teacher relationship was predictive of children's loving God concept, whereas mother-child attachment representation was not. Parents are postulated to be primary and strong agents for children's socialization and for transmitting to children the cultural norms of racial, ethnic, moral, and religious attitudes (Hyde 1990). It is in their home that children first learn about religion, or are taught (consciously or unconsciously) not to be religious. Parents have been found to foster the religiousness of children more strongly than schools (for an overview, see Hyde 1990). However, few studies deal with young children.

That children's God concept was not affected by the representation of the mother-child relationship can be explained in several ways. First, it may be due to the religiousness of the sample and the religious education at school. About 62.5 percent of the children came from nonreligious homes, only 37.5 percent of the sample was raised Christian. About 79 percent of the children received religious education at school, only 21 percent did not. It may be that children from nonreligious homes receiving religious education at school develop a God concept in the relationship with their teacher and adopt the teacher's God concept (Johnstone 1966 in Hyde 1990). Further research is needed to clarify whether our findings apply to a more diverse religious and socioeconomic sample. In addition, based on spiritual, cultural, and/or moral motives, many parents (nonreligious and secularized, as well as liberal Christian) in The Netherlands have been found to stress the importance of the religious domain for their children's upbringing, but do not know how to give structure to religious education, which leads them to choose denominational or religiously affiliated schools (Boersma 1998; Dijkstra, Dronkers, and Hofman 1997). These parents delegate their responsibility for religious education to teachers. Therefore, it may be that for many children in the contemporary secularized Dutch society teachers (of religiously affiliated schools) become more important as agents for religious socialization than are parents.

A second explanation may be the environment in which the data were collected (Coles 1990). The present study took place at school during normal school hours. It may be that children's God concepts are more influenced by parental factors when these concepts are measured at home than when they are measured at school. Another alternative explanation may be the measure of attachment. It is conceivable that observations of separation-reunion and secure base behavior in young children are more strongly related to God concepts than attachment representations. The expected effects of attachment representations on the valence of the God concept may emerge in older children. Future investigations should address these issues. 
Also, one might question the validity of the Incomplete Doll Stories Test. However, some meaningful associations of attachment representation with other variables were found. On a correlational level, security of the representation of the mother-child attachment relationship was positively related to a few aspects of working models, i.e., perceived cognitive competence $(r=$ $0.24, p<0.05$; cf. Verschueren and Marcoen 1999) and positive emotions $(r=0.25, p<0.05)$, but these correlations were too weak to yield a significant path in the Lisrel analyses. We did find a significant relation between the security of children's mother-child attachment representation and the quality of the child-teacher relationship. Young children with a secure representation of attachment to mother generally had a less discordant and a more close relationship with their teacher than young children with an insecure representation of attachment. This result is in line with previous research (Howes and Matheson 1992) and shows evidence for the convergent validity of the attachment doll stories measure.

Working models of others, i.e., perceived acceptance by peers, was not related to motherchild attachment representations or teacher-child relationships, but was predictive of a loving God concept. Kindergarteners who viewed themselves to be highly accepted by their peers had a more loving God concept than those who felt less accepted by peers. This finding is consistent with our hypothesis. To our knowledge, the present study is the first study to show a concurrent connection between perceived acceptance by peers and God concept of young children.

The finding that perceived acceptance by mother was not significantly related to any variable also deserves some attention. A few explanations can be offered for this finding. First, it may be due to a response pattern of the avoidantly attached children among the group of the more insecurely attached children. These children have been found to describe themselves and their attachment figure in an idealized, perfect way (Cassidy 1988). This response pattern may obscure true relations among the security of attachment representations, perceived acceptance by mother, and God concept. Second, it is conceivable that it is due to the nature of the measure used to assess acceptance by mother. In the pictorial scale, the child's self-evaluation concerning competence and acceptance is probed directly. Problems of direct self-report measures have already been discussed elsewhere (Verschueren and Marcoen 1999). It may be that indirect measures of the child's self (cf. the puppet interview, Verschueren and Marcoen 1999) yield more associations among attachment representations, self-evaluations, and God concept.

A final issue is that we found no relations of any variable with a punishing God concept. Loving and punishing God concepts are two distinctive dimensions and not two poles of a loving versus rejecting dimension. It may be that the punishing God concept in kindergarteners is predicted by other variables than the ones that predicted a loving God, e.g., the God concepts of the parents or the teachers. Or it may be that the antecedents included in the present study predict a punishing God in older children. It is also conceivable that a punishing God concept is less salient for young children in the present time than a loving God concept and, therefore, is less predictable than a loving God concept. This suggestion is in line with contemporary modern/postmodern theologies in which a loving God is emphasized, a wrathful God is shifted away from (Tieleman 1995; Tilley 1995). It is also consistent with results of recent empirical studies on God concepts among Dutch-speaking adolescents and adults (Hutsebaut 1998; Janssen and Prins 1998). These results demonstrated that, based on daily experiences, people reinvent their God image continuously. A personal construction of the concept of God is not in line with the traditional, punishing, wrathful, and authoritarian God image. The above-mentioned explanations for the finding that a punishing God concept was not related to any variable remain important topics for future investigations.

In conclusion, this study highlights the importance of the child-teacher relationship as a context for the development of self-esteem and a positive, loving God concept in early childhood. Teachers should recognize that the impact of their education on young children's view of themselves and God is not just limited to instruction skills, but also to the quality of the relationship they build with the children. 


\section{Note}

1. Religious education is not allowed within the regular curriculum of Dutch public elementary schools. There is only room for religious education on an optional basis in such schools, outside the responsibility of the school. However, religious education is an integral part of all denominational or religiously affiliated (e.g., Protestant or Catholic) schools (De Ruyter and Miedema 2000).

\section{REFERENCES}

Bartholomew, K. and L. M. Horowitz. 1991. Attachment styles in young adults: A test of a four-category model. Journal of Personality and Social Psychology 61:226-44.

Benson, P. and B. Spilka. 1973. God image as a function of self-esteem and locus of control. Journal for the Scientific Study of Religion 12:297-310.

Blaine, B. E., P. Trivedi, and A. Eshleman. 1998. Religious belief and the self-concept: Evaluating the implications for psychological adjustment. Personality and Social Psychology Bulletin 24:1040-52.

Boersma, P. 1998. School en religie. [School and religion.] In Christelijk onderwijs in ontwikkeling. Jaarboek 1997, edited by S. Miedema and H. Klifman, pp. 65-73. Kampen: Uitgeverij Kok.

Bowlby, J. 1973. Attachment and loss: Vol. 2. Separation. New York: Basic.

Brennan, K. A. and J. K. Bosson. 1998. Attachment-style differences in attitudes toward and reactions to feedback from romantic partners: An exploration of the relational bases of self-esteem. Personality and Social Psychology Bulletin 24:699-714.

Brennan, K. A. and K. A. Morris. 1997. Attachment styles, self-esteem, and patterns of seeking feedback from romantic partners. Personality and Social Psychology Bulletin 23:23-31.

Bretherton, I. 1985. Attachment theory: Retrospect and prospect. Monographs of the society for research in child development 50 (1-2, Serial no 209):3-35.

Buri, J. R. and R. A. Mueller. 1993. Psychoanalytic theory and loving God concepts: Parent referencing versus selfreferencing. Journal of Psychology 127:17-27.

Cassidy, J. 1988. Child-mother attachment and the self in six-year-olds. Child Development 59:121-34.

Coles, R. 1990. The spiritual life of children. Boston, MA: Houghton Mifflin Company.

Collins, N. L. and S. J. Read. 1990. Adult attachment, working models, and relationship quality in dating couples. Journal of Personality and Social Psychology 58:644-63.

De Meester, I. and M. Verkerk. 1999. De invloed van de opvoedingsstijl en godsdienstige denkbeelden van de ouders op het godsbeeld en zelfbeeld van een kleuter. [Influences of parental child-rearing practices and religious beliefs on the concept of self and God in kindergarteners.] Unpublished masters thesis. Amsterdam: Vrije Universiteit.

De Ruyter, D. J. and S. Miedema. 2000. Denominational schools in the Netherlands. In Education, culture, and values Volume V. Spiritual and religious education, edited by M. Leicester, C. Modgil, and S. Modgil, pp. 133-41. London and New York: Falmer Press.

Dickie, J. R., A. K. Eschleman, D. M. Merasco, A. Shepard, M. Vander Wilt, and M. Johnson. 1997. Parent-child relationships and children's images of God. Journal for the Scientific Study of Religion 36:25-43.

Dijkstra, A. B., J. Dronkers, and R. Hofman. 1997. Verzuiling in het onderwijs. [Pillarization in the field of education.] Groningen: Wolters-Noordhoff.

Ellison, C. G. 1993. Religious involvement and self-perception among black Americans. Social Forces 71:1027-55.

Feeney, J. A. and P. Noller. 1990. Attachment style as a predictor of adult romantic relationships. Journal of Personality and Social Psychology 58:281-91.

Goossens, F. A. and M. H. van IJzendoorn. 1990. Quality of infants' attachments to professional caregivers: Relation to parental attachment and day care characteristics. Child Development 61:550-67.

Haltiwanger, J. 1989. Behavioral referents of presented self-esteem in young children. Poster presented at the Biennial Meetings of the Society of Research in Child Development, Kansas City, Missouri, April 1989.

Haltiwanger, J. and S. Harter. 1988. A behavioral measure of young children's presented self-esteem. Unpublished manuscript. Denver, CO: University of Denver.

Harter, S. and R. Pike. 1984. The pictorial scale of perceived competence and social acceptance for young children. Child Development 55:1969-82.

Howes, C., C. E. Hamilton, and C. C. Matheson. 1994. Children's relationships with peers: Differential associations with aspects of the teacher-child relationship. Child Development 55:253-63.

Howes, C. and C. C. Matheson. 1992. Contextual constraints on the concordance of mother-child and teacher-child relationships. In Relationships between children and non-parental adults: New directions in child development, edited by R. C. Pianta, pp. 25-40. San Francisco, CA: Jossey-Bass. 
Hutsebaut, D. 1998. Omgaan met geloof en godsdienst: Ontwikkeling of bepaald door opvoedingsmodel? Een analyse van gegevens van personen tussen 18 en 90 jaar. [Dealing with faith and religion: Development or affected by a model of childrearing? An analysis of data from subjects aged between 18 and 90 years.] In Schering en inslag. Opstellen over religie in de hedendaagse cultuur, edited by J. Janssen, R. van Uden, and H. van der Ven, pp. 18-31. Nijmegen: KSGV.

Hyde, K. E. 1990. Religion in childhood and adolescence: A comprehensive review of the research. Birmingham, AL: Religious Education Press.

Janssen, J. and M. Prins. 1998. "Let's reinvent the Gods.” De religie van Nederlandse jongeren in een Europese context. [The religion of Dutch adolescents in an European context.] In Schering en inslag. Opstellen over religie in de hedendaagse cultuur, edited by J. Janssen, R. van Uden, and H. van der Ven, pp. 123-38. Nijmegen: KSGV.

Jöreskog, K. G. and D. Sörbom. 1993. Lisrel 8: Structural equation modelling with the SIMPLIS command language. Hilldale, NJ: Lawrence Erlbaum Associates.

Kirkpatrick, L. A. 1998. God as a substitute attachment figure: A longitudinal study of adult attachment style and religious change in college students. Personality and Social Psychology Bulletin 24:961-73.

- 1999. Attachment and religious representations and behavior. In Handbook of attachment: Theory, research, and clinical applications, edited by J. Cassidy and P. R. Shaver, pp. 803-22. New York and London: Guilford Press.

Kirkpatrick, L. A. and P. R. Shaver. 1992. An attachment-theoretical approach to romantic love and religious belief. Personality and Social Psychology Bulletin 18(3):266-75.

Kobak, R. R. and A. Sceery. 1988. Attachment in late adolescence: Working models, affect regulation, and representations of self and others. Child Development 59:135-46.

Mikulincer, M. 1995. Attachment style and the mental representation of the self. Journal of Personality and Social Psychology 69:1203-15.

Pianta, R. C. 1996. Manual and scoring guide for the Student-Teacher Relationship Scale. Unpublished manuscript. Charlottesville, VA: University of Virginia. . 1997. Adult-child relationship processes and early schooling. Early Education and Development 8:11-26.

Smith, C. B., A. J. Weigert, and D. L. Thomas. 1979. Self-esteem and religiosity: An analysis of Catholic adolescents from five cultures. Journal for the Scientific Study of Religion 18:51-60.

Spilka, B., J. Addison, and M. Rosensohn. 1975. Parents, self, and God: A test of competing theories of individual-religion relationships. Review of Religious Research 16:154-65.

Sroufe, L. A. 1983. Infant-caregiver attachment and patterns of adaptation in the preschool: The roots of competence and maladaptation. In Minnesota Symposia in Child Psychology, edited by M. Perlmutter, Vol. 16, pp. 41-83. Hillsdale, NJ: Lawrence Erlbaum Associates.

Tamminen, K. 1991. Religious development in childhood and youth: An empirical study. Helsinki: Suomalainen Tiedeakatemia.

Tieleman, D. 1995. Geloofscrisis als gezichtsbedrog. Spiritualiteit en pastoraat in een postmoderne cultuur. [Crisis in faith as an optical illusion. Spirituality and pastoral care in a postmodern culture.] Kampen: Uitgeverij Kok.

Tilley, T. W. (ed.). 1995. Postmodern theologies. The challenge of religious diversity. Maryknoll and New York: Orbis Books.

Verschueren, K. and A. Marcoen. 1994. Test met gehechtheidsverhalen. Classificatiesysteem. Aanpassing van de Doll Stories Completion Task van Cassidy (1986) voor gebruik bij 4,5 tot 6-jarigen. [Adaptation of the Doll Stories Completion Task (Cassidy, 1986) for use with 4.5- to 6-year-olds: Classification system.] Unpublished manual. Center for Developmental Psychology, University of Louvain.

. 1999. Representation of self and socioemotional competence in kindergarteners: Differential and combined effects of attachment to mother and to father. Child Development 70:183-201.

Verschueren, K., A. Marcoen, and V. Schoefs. 1996. The internal working model of the self, attachment, and competence in five-year-olds. Child Development 67:2493-2511. 